\title{
RETRACTED: Penanaman Nilai-Nilai Islam dalam Membentuk Sopan Santun Anak di Raudlatul Athfal Yayasan Nurul Bahra Kabupaten Bone Hermanto ${ }^{1}$ *
}

${ }^{1}$ STAI Al-Gazali Soppeng

ARTICLE INFO ABSTRACT

\section{ARTICLE HISTORY}

Received: 09 Okt. 2019

Revised: 09 Okt. 2019

Accepted: 09 Okt. 2019

\section{KEYWORDS}

pendidikan; anak usia dini; sopan santun; education; early childhood; polite manners

\section{RETRACTED}

Following a rigorous and careful concerns and consideration in the review of the article published in An Nisa' entitled 'Penanaman Nilai-Nilai Islam dalam Membentuk Sopan Santun Anak di Raudlatul Athfal Yayasan Nurul Bahra Kabupaten Bone" Vol 12, No 1, pp. 560-569, Juni 2019, DOI: http://dx.doi.org/10.30863/annisa.v12i1.450

This paper has been found to violate the principles of An Nisa' Publication and has been retracted.

The article has contained redundant material and throughout a careful examination, the editor has found that the paper has also been published in Cakrawala Dini: Jurnal Pendidikan Anak Usia Dini, Vol. 10, No. 1, pp. 31-41, 2019, DOI: http://dx.doi.org/10.17509/cd.v10i1.15756

The document and its content have been removed from An Nisa', and reasonable effort should be made to remove all references to this article.

CONTACT: Hermanto $₫$ hermanto@gmail.com $\equiv$ STAI Al-Gazali Soppeng 